\title{
A mulher no pedestal: representações de feminilidade e cristianismo na escrita masculina do periódico ouro- pretano $O$ Noticiador de Minas (1869-1873)
}

\author{
The Woman Put on A Pedestal: Femininity and Christianity Representations \\ in Masculine Writing in Ouro-Preto's Newspaper O Noticiador de Minas
} (1869-1873)

Matheus da Cruz e Zica *

\begin{abstract}
Resumo
Esse artigo tem por objetivo discutir sobre como determinadas imagens associadas ao universo cristão são mobilizadas por alguns jornalistas ao falarem sobre mulheres. As décadas de 1860 e 1870 deram lugar a grandes mobilizações feministas mundo afora e dentro do próprio Brasil. Entretanto, setores específicos da sociedade procuraram manter as mulheres afastadas do espaço público. Parece ser esse o caso dos colaboradores do jornal ouro-pretano O Noticiador de Minas, entre os anos de 1869 e 1873 . Segundo inúmeros viajantes europeus que visitaram aquela região ao longo da primeira metade do século XIX, o costume masculino de prender as esposas em casa era sobejamente difundido. Essa carga cultural, condensada ao longo de décadas, não seria abandonada assim tão facilmente e muitos homens daquela região, afeiçoados aos seus privilégios, parecem ter se valido do jornalismo e de referências cristãs na tentativa de manter os antigos costumes. Abusando da representação da mulher bela e da mulher mãe, esquivaram dos olhares atentos de seus leitores outras representações já disponíveis para aquele período, como a mulher intelectual ou a mulher empregada pública.
\end{abstract}

Palavras-chave: representações culturais; mulheres; referências cristãs; século XIX; Minas Gerais.

\begin{abstract}
This article aims to discuss how specific images associated to the Christian worldview are taken by some journalists while writing about women. In the 1860's and 1870's, great feminist demonstrations took place not just around the world but also in Brazil. However, particular sectors of society attempted to keep women out of public space. This seems to be the case of Ouro Preto's newspaper O Noticiador de Minas journalists between 1869 and 1873. Countless European travelers who had visited Ouro-Preto region through the first half of the 19th century reported the masculine practice of keeping wives enclosed at home. This cultural charge, condensed through the decades, would not be abandoned so easily as many men of the region, seduced by their male privileges, seemed to have used journalism and Christian references in order to keep ancient cultural habits. Abusing woman representation of beauty and maternity, those men avoided their readers from alternative woman representation already available at the time, such as the woman as an intellectual or as a public servant.
\end{abstract}

Keywords: cultural representations; women; Christian references; the 19th century; Minas Gerais.

Artigo recebido em 15 de maio de 2014 e aprovado em 18 de setembro de 2014.

* Doutor em História da Educação pela UFMG, e Pós-doutor pelo Programa de Pós-Graduação em Educação da FaE/UFMG. Professor Adjunto do Departamento de Fundamentação da Educação do Centro de Educação da UFPB.

País de origem: Brasil. E-mail: matheusczica@gmail.com 


\section{Introdução}

$\mathrm{Na}$ pesquisa que realizamos no doutorado a respeito dos discursos educativos direcionados e produzidos por e para sujeitos do gênero masculino no século XIX (ZICA, 2011), verificamos que os relatos de viajantes estrangeiros que passaram por Minas Gerais ao longo daquele século descreveram com frequência certos costumes ligados a tradições dos tempos do Brasil colonial, no que tange às relações de gênero. Já nos Relatórios dos Presidentes da Província de Minas Gerais encontramos algumas propostas e iniciativas para que novas formas de relações de gênero surgissem.

No caso dos jornais, principalmente no do Noticiador de Minas - o mais bem documentado referente ao período e o que será mais explorado por nós nessa ocasião já que, talvez pela menor quantidade de números dos demais, não encontramos nada de muito significativo para nossa pesquisa nesses - a escrita masculina que o conforma revela outra face do entrecruzamento entre tradição e modernidade, no que diz respeito às relações entre homens e mulheres, que se desenrola naquele contexto.

Os discursos veiculados no referido jornal também trazem pistas a respeito da maneira como esse processo de entrelaçamento entre tradição e modernidade está afetando os homens envolvidos com a produção e recepção daquele periódico. Aqueles homens pareciam se sentir cada vez mais compelidos a escrever sobre o assunto ainda tenhamos de reconhecer, entretanto, que tal temática jamais tenha sido o foco principal de qualquer uma das edições do Noticiador de Minas.

Apenas alguns jornais de Ouro Preto que cobrem o período de 1869 a 1872 foram conservados. Estes se encontram micro-filmados ou na Hemeroteca do Estado de Minas Gerais ou digitalizados e disponíveis no site do Arquivo Público Mineiro, sob o título de Jornais Mineiros (SIAAPM, 2014). Conforme já dissemos, a coleção mais completa é a do periódico do Partido Conservador - e ao mesmo tempo oficial - Noticiador de Minas, que cobre todo o ano de 1869, a segunda 
metade de 1870 e os anos inteiros de 1871 e 1872. Encontramos também poucas edições que vão de Novembro de 1869 a Maio de 1870 do também conservador Dezesseis de Julho, publicado no Rio de Janeiro, mas preocupado com assuntos que diziam respeito à província de Minas Gerais; e as escassas edições referentes a dois meses, Fevereiro e Março de 1870, de outro periódico conservador, o Conservador de Minas. Mas a maior falta que se faz sentir é a de mais edições do Liberal de Minas, ao que parece, a julgarmos pelas polêmicas que podemos ler no Noticiador de Minas, o principal rival dos Conservadores naquele contexto na província. Desse período há apenas dois exemplares: a edição de número 56, de 09/09/1869 e a de número 98, de 21/04/1870. Por conta dessas questões privilegiamos aqui a análise de artigos do $O$ Noticiador de Minas.

Podemos adiantar que na maioria das vezes em que os homens se valeram da escrita nesse jornal em incursões nas temáticas dos “sexos”, como comumente se referiam, parece ter sido para se defenderem de um avanço feminino nos campos da política e da legalidade que se operava no mundo ocidentalizado do período. Embora as reivindicações feministas não tenham sido tão contundentes por aqui quanto em países como Alemanha, Inglaterra e EUA (GAY, 1988 [1984], p. 131-142; GAY, 1995 [1988], p. 331-370) - embora isso não queira dizer que elas tenham sido inexistentes no Brasil (MUZART, 2003) ou em Minas Gerais (FARIA FILHO, 2005, p. 72-81) -, o que a análise do jornal oficial da capital da província, entre os anos de 1869 e 1872, nos mostra é que seus editores, leitores e vários colaboradores se mostravam bastante prevenidos contra elas e para isso se valeram muitas vezes de referências cristãs para essa empresa. É aqui que se entrecruzam os interesses dos Estudos de Gênero, da História da Educação e das Ciências das Religiões.

Da mesma forma que isso evidencia um apego desses homens às tradições e aos privilégios masculinos que, segundo os relatos de viajantes europeus que visitaram Minas Gerais, caracterizavam a região até aquele momento, traz também à tona outra face do processo pelo qual passa uma parcela da masculinidade no 
mundo ocidental do período. Para nós, a ansiedade dos homens por exaltarem a beleza feminina, elogiarem o lugar de mãe e sua importância para a família - que no século XIX se trata sempre de um grande argumento (PERROT, 2009 [1987]; SCOTT, 1999) - e utilizarem com tanta freqüência a ironia contra as mulheres, no fundo acaba indiciando que um sentimento de insegurança parecia os rondar, conforme tentaremos detalhar mais adiante.

Sabemos que, devido à falta de outros jornais, a impressão que obtivemos a partir da análise do Noticiador de Minas, deve ser tomada com cautela quanto às pretensões de generalização. Mas o fato de tal jornal, que para o período tem uma longevidade considerável e que se comparado a outros da mesma época tem boa qualidade de impressão - uma vez que traz muitas imagens, inexistentes nos demais -, ser o principal e praticamente o único periódico ouro-pretano remanescente daqueles anos já o torna relevante o bastante para nos ajudar a melhor compreender as relações de gênero no período, mesmo que diga apenas da parte dos homens que estiveram envolvidos ou com sua produção ou com sua recepção.

\section{Os sentidos da mobilização de referências cristãs para uma representação do ser mulher}

O Noticiador de Minas traz um artigo copiado de outro periódico - Novo Mundo - que foi veiculado na edição 336 (25/07/1871), única matéria a abordar o tema da mulher no espaço público durante os quatro anos em que acompanhamos o jornal, intitulado "A mulher como empregada pública”, no qual o autor anônimo mostra admiração pelo modelo americano:

Poucas coisas têm-se adiantado tanto neste ultimo decennio, como a dos direitos das mulheres. Não sendo nós de opinião que é do papel das senhoras ir à sachristia da parochia rubricar-se como votante e depois disso ir fazer eleitores e deputados (e não queremos pelo próprio amor dellas), todavia, cremos que em todo paiz civilisado se deve abrir porta franca à concurrencia da mulher nos empregos e profissões para que a natureza a dotou com qualidades pelo menos iguaes ao do commum dos homens que desempenhão essas profissões. 
Em 1862 não havia nos Estados-Unidos uma só mulher empregada em repartições governamentais. Nesse ano tinha já rebentado a guerra com o sul dos Estados, e o ministro da fazenda, que precisava de um grande número de empregados para contar, dividir e aparar com thesoura as pilhas de papel moeda que então se emittirão resolveu admittir senhoras a este serviço. Então 65 foram empregadas na repartição do thesoureirogeral, com o ordenado de $120 \$$ por mez. Logo depois, a repartição das rendas admittio 40, e de então para cá o número tem-se augmentado muito. Hoje só no departamento do thesoureiro há 218 empregadas; no das rendas internas há 90; secção há 150 e nas outras secções do ministério há cerca de 200, fazendo um total de cerca de 700 senhoras empregadas em todo thesouro. (Jornal $O$ Noticiador de Minas, edição $336,25 / 07 / 1871)$.

Lembramos que essa saída feminina do lar nos próprios Estados Unidos da América parece não ter ocorrido sem causar alguma reação masculina, a mesma que vemos grassar no nosso jornal antes mesmo que as reivindicações chegassem por aqui com a intensidade que tinham por lá - lembremos que o autor de maneira um tanto defensiva, logo de início, descarta seu apoio à concessão do direito de voto às mulheres, prevenindo-se de uma bandeira sabidamente já bastante abraçada por vários setores naquele mesmo país que ora se tomava como modelo. Em relação às lutas travadas pelos movimentos feministas na segunda metade do XIX, Peter Gay (1984 [1988], p. 144) demonstra que elas foram percebidas por vários homens nos Estados Unidos da América através de imagens em que se misturam as vestimentas femininas e o vento forte que pode arrastar quem estiver pela frente:

Ocasionalmente, os antifeministas em toda intensidade primitiva desistiam das pretensões humorísticas para expor o medo que o homem tinha da mulher. Num discurso que proferiu da tribuna da Câmara dos Deputados a 30 de maio de 1872, Stevenson Archer, de Maryland, advertia que "o sufrágio feminino não pode ser tolerado, apesar de ser apoiado pelo candidato republicano à vice-presidência". O movimento havia se tornado uma ameaça, advertia Archer; "esses inovadores" já não eram mais "meros arlequins em espartilhos"; de fato, "um exército monstruoso está vindo ao nosso encontro - 100 mil 'tufões vestidos de anáguas' - , e nós precisamos enfrentá-lo com firmeza para não sermos esmagados pelo vendaval. A pequenina mulher atingiu tal tamanho e força que suas estocadas já fazem gemer o grande homem; suas unhas delicadas transformaram-se em garras de águia, que agora arrancam a carne que antes afagavam; e se o rapagão bem-disposto não se puser rapidamente em guarda, será estrangulado, derrubado e forçado a aceitar condições com as quais até pouco tempo atrás não teria nem sonhado”. 
Sabendo da existência desse medo e ansiedade que a "saída feminina oficial" parece causar a muitos homens do período, compreendemos melhor porque o mais comum nas várias edições que acompanhamos do Noticiador de Minas não eram os textos sobre a mulher trabalhadora - como já dissemos, a esse respeito só encontramos aquele citado acima - mas sim os que se esforçavam em reiterar a exaltação tanto do ideal de beleza da feminilidade, quanto o da missão da mulher na família, sobretudo em seu papel de mãe. Podemos ver isso com clareza no número 423 (27/03/1872), em artigo intitulado "A religião e a mulher Impressões no Templo", no qual o autor anônimo escreve sobre as sensações que teve ao ouvir o canto de algumas mulheres em uma missa. Após elogiar a religião cristã, o articulista passa então a dizer das relações dessa com as mulheres:

Mas em que ponto o christianismo estampou toda a sua sublimidade? Onde o seu verbo divino reflectiu com todo o fulgor senão na mais bella parcella, em cuja criação Deus como que se havia esmerado, senão na mulher? Limittada até então a ser uma humilde companheira do homem e até sua escrava, entregue aos mais rudes e materiaes interesses, o christianismo faz surgir a aurora da sua redenpção, nobilitou-a, enobreceu-lhe o espírito, povoou-lhe o coração dos mais bellos e ineffáveis sentimentos, tornando-o verdadeiro sacrário de verdadeiras virtudes.

[...]

E quanto mais a sociedade se aperfeiçoa, quanto mais a civilisação inspirando-se nas verdades luminosas estampadas nas paginas sacrossantas da Bíblia caminha, avança para o último gráo de sua perfectibilidade, tanto mais a mulher nobilita-se, eleva-se para a consecução de todos os destinos que lhes forão assignados por Deus.

[...]

Mas, a religião do Christo não consiste em verdades abstractas, nem em práticas estéreis, e sim em um culto ideal e sensível que a distingue de todas as religiões que a imaginação do homem há creado. Para a mulher a religião christã é ainda uma gratidão, porque nobilitou-a, collocou-a à par o homem, elevou-a ao gráo de santidade.

(Jornal O Noticiador de Minas, edição 423, 27/03/1872).

Na edição 338 do mesmo jornal, no ano anterior ao da publicação do último artigo citado (01/08/1871), num texto intitulado "A mulher", e assinado por Dr. Antônio Manoel dos Reis, encontramos vários dos elementos presentes na última citação que fizemos do jornal:

A mulher é o encanto da creação, o ídolo das nossas adorações, o palpite dos nossos peitos, o scismar das nossas almas.

[...] 
Quantos thesouros não tem conferido ao mundo, esse sexo, no qual a natureza depositou tudo quanto há de mais seductor nas formas, de mais deslumbrante na formosura, de mais bello na imaginação?!... O coração da mulher é um altar onde os homens sacrificão ao amor; é o cofre onde se encerrão os mais nobres sentimentos, as mais elevadas virtudes.

$[\ldots]$

Importante e nobre é o papel que ella representa no mundo, já simplesmente como mulher, já como esposa, e já como mãi. Mulher, ella é uma gota do nosso sangue e o ponto para onde convergem nossos pensamentos e acções; - esposa, ella é um anjo que a Divindade fez baixar do céo, para associar-se aos nossos prazeres e entristecer-se com a nossa desdita; mãi, ella é tudo quanto se pode imaginar de mais elevado no coração humano. É o pharol que nos guia pelo caminho da honra e do dever, desviando nossos passos do abysmo do vicio e do crime. (Jornal O Noticiador de Minas, edição 338, 01/08/1871).

Os articulistas, como vimos, também gostavam bastante de falar em história e nisso o Dr. Reis não fugiu à regra:

Recorra-se às páginas da história e ahi achar-se-ha exemplos edificantes de piedade, amor materno e heroísmo! Ver-se-ha virgens pudibundas e matronas respeitáveis, caminharem de fronte erguida, passo firme, e de olhos enxutos, para o altar do sacrifício, deixando rolar as cabeças pelos ensangüentados degraos do cadafalso, por dedicação à pátria, fidelidade aos esposos e amor aos filhos! Escrava na China, desprezada no Japão, na Malásia, Sumatra, Phillipinas e outras ilhas; vendida na África, castigada barbaramente na Núbia; felizmente entre os povos onde a civillisação tem dissipado as espessas sombras da ignorância, a mulher representa importantíssimos papéis no seio da família, na sociedade, nas artes e na litteratura. (Jornal O Noticiador de Minas, edição 338, 01/08/1871).

\title{
Esse tipo de raciocínio expresso nesses artigos evidencia o compartilhamento de experiências, preocupações e visões de mundo entre homens de diferentes regiões que viviam naquela mesma época. Segundo Peter Gay, muitos outros homens também o utilizaram como reação ao mesmo avanço feminino que experimentavam:
}

\begin{abstract}
Em meados da década de 1850, John Chapman, editor da liberal Westminster Review, apresentou a crescente influência da mulher ao longo das eras como um capítulo no progresso moral da humanidade. $\mathrm{Na}$ barbárie e na Antigüidade, a mulher era tratada como criança, uma trabalhadora, e uma dependente sem defesas à disposição da luxúria do homem. Mas com a passagem dos séculos "a mais baixa escrava do homem se tornou a principal influência sob a qual ele vive, sua inspiração na batalha, sua companhia mental, a encarnação da beleza, do amor, da
\end{abstract}


devoção, do sagrado, a fonte e o tema da poesia - obrigando os mais nobres a adorar em seu altar". Fazer a história da mulher como uma ascensão da servidão à liberdade, tão deliciosa de olhar, passou a ser um esporte favorito dos jornalistas. Não ficavam desconcertados com o fato de que sua argumentação se apoiava em materiais históricos escassos e ruins e que seu alegre relato da evolução inspiradora da mulher era apenas mais um estratagema para esquivar-se às questões contemporâneas. Claramente, para eles, a mulher como alta sacerdotisa do bom e do belo não precisava das marcas superficiais do poder - mais instrução e direito de voto - para exercer sua supremacia. (GAY, 1995 [1988], p. 298-299).

É interessante que no mesmo número do jornal citado anteriormente outro artigo - sobre regimes de governo - traga uma citação de John Stuart Mill, designado no texto como um "liberal inglês". Parece que o seu livro Systema Representativo teria sido mais aceito que seu outro livro recém lançado àquela época, A sujeição das mulheres, publicado em 1869, que, segundo Peter Gay (1988 [1984], p. 131-132), "viria a ser a obra-chave da história do feminismo", tamanha a contundência das denúncias que nele fez das injustiças legitimadas pelo código inglês para com as mulheres até aquele momento. Pelo que pudemos perceber, para falar de mulheres os jornalistas do Noticiador de Minas pareciam preferir outros autores, outros assuntos e outras abordagens, bem distantes das questões que Stuart Mill trazia para a ordem do dia...

Na edição 514 (06/12/1872), o quarteto História-Mulher-Religião-Família aparecerá dessa vez no gênero poético. Trata-se de "A creação da mulher”, assinada por A. J. de Macedo Soares, da qual trazemos o trecho final:

De um verbo o homem nasceu! No olhar altivo

Brilhava a chamma que avassalla os mundos;

$\mathrm{E}$ ao sentir dentro de si germens fecundos

Hymnos de gloria alçou ao Creador.

Mas da vida os encantos, a alegria

Não resumem os gozos da sciencia;

Si enlevada sorria a intelligencia

Gemia o coração n’ancia do amor.

Deus escutou as preces do proscripto

E o pranto abençoou do peregrino!

E d'um raio de luz do olhar divino

Surgio na terra a estatua da mulher.

Sublime Prometheu; do amor ao fogo

Nella o homem fundio su'alma e vida;

Esposa, mãi, irmã, filha querida

Unio a della a essência de seu ser. 
Virgem, que tua historia ouves narrada

Nos toscos versos de uma pobre Lyra,

Segue o norte da estrella que te inspira

Dessa mãi que por ti vive feliz!

Lume do olhar de Deus! Possa em tu'alma

Sempre fulgir da crença a luz radiante

E em teu peregrinar no mundo errante

Brotar flores e perolas gentis!

(Jornal O Noticiador de Minas, edição 514, 06/12/1872).

Nessa mesma linha outra poesia sugestivamente intitulada "A mulher", publicada dez números antes dessa última, edição 504 (07/11/1872), também não parecia estar muito preocupada com as novas representações de mulher que a modernidade fazia surgir. Como na poesia anterior, mais uma vez o autor, desta vez Augusto Frederico Colin, irá lembrar a origem bíblica da mulher e de sua necessária vinculação ao homem, a quem devia servir com sua extrema bondade e beleza com que Deus a dotou:

Tal a vida!.. O Omnipotente, Providente, Juncto à noite poz o dia.

- Ao sol a sombra, e ao claor

O frescor -,

Com a mais sublime harmonia.

Como um astro radiante, Coruscante, Do mais límpido fulgor, Na terra alçou magestosa, Portentosa,

A mulher - anjo d'amor!

De teus lábios nacarados, Perfumados, Dimana a consolação; Meigo sorrir delicado, Doce agrado, Branda paz ao coração.

É su' alma um templo immenso, Onde o incenso, Vive sempre a fumegar, Como um hymno que da terra Se descerra

Para a Deos louvores dar. 
Oh virgem! Tal é teu fado,

Consagrado,

Nos decretos do Senhor;

Teu ser a terra abrilhanta

Como encanta

No prado cheirosa flor.

[...]

(Jornal O Noticiador de Minas, edição 504, 07/11/1872).

Talvez possamos relacionar essa recorrente associação positiva entre a mulher e as referências cristãs não só a um indício do processo que Maria José F. Rosado Nunes (1996, p. 503-513) chamou de "feminização do catolicismo brasileiro" que teria ocorrido ao longo do século XIX, como também da boa acolhida que ele parece ter alcançado entre os homens em Minas Gerais. Dentre as várias características desse processo de feminização do catolicismo estaria a valorização que a Igreja Católica passou a empreender em relação às figuras femininas bíblicas. É no século XIX que as leituras negativas da Eva pecadora perdem espaço para o culto de Maria (LIMA; TEIXEIRA, 2008, p.113-126). Isso se devia em boa parte à estratégia que a Igreja Católica havia traçado para conter o avanço do laicismo que aqueles anos dos oitocentos assistiam, principalmente entre os homens. Para isso, ela mobilizou a mulher como um elemento-chave da reforma interna que teve de empreender ${ }^{1}$ (ROSADO NUNES, 1996, p.507-508). Os cultos passaram a começar mais cedo, no horário de trabalho dos homens; as igrejas começaram a contar muito mais com a presença das mulheres; além de uma disseminação de colégios católicos femininos no período.

Um aspecto que deve ser ressaltado é que a valorização que a Igreja passa a empreender em relação às mulheres se direciona, sobretudo, à condição que deviam assumir de esposas e mães. Raquel Martins de Assis (2004, p. 228-238) encontra isso de maneira muito explícita na pesquisa que fez sobre o periódico Selecta Catholica, principal expoente do pensamento da Igreja em Minas Gerais em meados do século XIX. Sobre a figura feminina nas páginas do jornal ela afirma

\footnotetext{
${ }^{1}$ Nestor Duarte já tinha se sensibilizado para essa característica, embora não tenha precisado o fenômeno como uma característica do século XIX, já que generalizava sua afirmação também para o período da colônia "A religião católica tem uma predileção especial pela criança e pela mulher, como centros mais aptos à sua influência moral e pedagógica, para atingir ao fim de sua tarefa de ortodoxia. Religião mais feminina do que masculina, no Brasil pelo menos." (DUARTE, 1966 [1939], p.77).
} 
que "ao tentar esclarecer a importância da vida familiar para o bom andamento da sociedade, os redatores da Selecta Catholica se preocupam amiúde com o papel da mulher na condução da família” (ASSIS, 2004, p.228). Esclarece ainda que em sua leitura percebeu que para o pensamento católico do período:

à mulher cabe o papel de cuidar da economia doméstica e de preocupar-se com o futuro familiar. E como a esposa é a pessoa designada para cuidar das questões internas da família, a tarefa da educação na infância é responsabilidade da mãe, pois segundo o jornal, os homens não são tão capazes de educar as crianças. (ASSIS, 2004, p.229).

Ternas e sacrificadas em nome da boa educação dos filhos e do bem-estar de seus lares, elas seriam as principais guardiãs da fé católica em crise. Em troca dessa importante missão a elas confiada, a Igreja lhes pedia obediência e resignação, lhes pedia que fossem modelos vivos de bondade e doação no lar (LIMA; TEIXEIRA, 2008, p.125-126). Não seria esse um modelo feminino bastante indicado para uma masculinidade que, para além de estar se tornando mais laica, está acima de tudo sendo marcada principalmente pelo questionamento de sua antiga hegemonia no domínio dos poderes de decisão? Nas páginas do Noticiador de Minas podemos ver tanto que os homens que nele escrevem estão se sentindo ameaçados pelas mulheres, pois estão numa postura defensiva, quanto que os mesmos pareciam estar bastante satisfeitos com essa manobra feita pela Igreja ao longo daquele século, a ponto de tomarem fragmentos de discursos católicos como seus. Repetiam muito esse ideal de mulher, presente nos discursos católicos do período, na condição de esposa/mãe terna e bondosa.

Nesse sentido, não é inverossímil supormos que a peça de teatro "O Anjo da Paz”, apresentada em Ouro Preto naqueles dias - sua propaganda está na edição 156 (09/10/1869) - tivesse como protagonista uma personagem feminina. Essas mulheres, convenientemente representadas por esses homens como anjos de paz, de amor, de bondade e de beleza, corriam, no entanto, segundo os mesmos homens, muitos perigos. Dentre eles o teatro, o baile, o romance, e até os primos serão apontados como ameaças à tamanha pureza existente nas mulheres. 
Acompanhemos um trecho do artigo intitulado "Os primos", assinado, sintomaticamente, por um(?) certo Mephistopholes - figura da tentação - e transcrito do Correio Pernambucano, na edição 395 (05/01/1872):

Dizem geralmente os moralistas da epocha que o baile, o theatro e o romance são as maiores seducções da família. Engano manifesto! Há uma seducção mais terrível e menos supportável que o theatro, o baile e o romance: é o primo.

Se uma menina disser por exemplo:

- Passei hontem a noite no theatro!

- Estive antes de hontem n'um baile!

- Acabei de ler um romance hoje!

Deve causar menos impressão que se ella disser sorrindo:

- Meu primo esteve hontem ao pé do piano conversando comigo.

Ninguém pode saber ao certo o que vai de medonho nessa declaração!

Um primo ao pé do piano! As palavras murmuradas entre os sons vibrantes da tecla que estremece; o segredo, o jogo do espírito velado pelo mysterio, o raio do olhar, a respiração suffocada, tudo isso é o que há de mais assustador para a tranqüilidade das famílias.

(Jornal O Noticiador de Minas, edição 395, 05/01/1872).

A sociedade do século XIX também convive com a antítese do modelo feminino de pureza e candura: a prostituta. Essa figura aparecerá na ed. 34 (10/11/1868), num texto de autor anônimo intitulado "A prostituição". Mas, ao invés de reprovar os homens que a patrocinavam, é a mulher prostituta que aparecerá como a grande culpada. Sobretudo por que elas subverteriam o que para eles seria a sagrada missão feminina: maternidade e exemplo de virtude. Assim, utilizavam o avesso do modelo para justamente reforçá-lo, como podemos ver nos trechos:

Não pode haver quadro mais triste do que o da prostituição, nem vida mais miserável, e tão cheia de horror. É a escada por onde a mulher sobe para buscar o título da degradação, e receber a coroa do repúdio que a sociedade lhe offerece. [...] A figura da mulher que se envolve nessa túnica de corrupção, é tão medonha que faz recuar o coração que possue os dotes angélicos da virgindade, que faz tremer o espírito sem poder exprimir a linguagem santa, que fortalece e enobrece o coração da mulher forte.

[...]

Um ente tão caro, que forma a ventura da sociedade, que sabe comprehender os affectos d'alma, não sei como possa romper esses laços, e escolher uma missão tão vil, para viver sempre desgraçada e infeliz! [...] é riscar de seu pensamento que é livre, de que foi creada para ser mãi, e para legar à humanidade filhos que abençoassem sua memória, e jamais se esquecessem de suas virtudes!

(Jornal O Noticiador de Minas, edição 34, 10/11/1868). 
Cinco edições depois - no n.39 (21/11/1868) - o tema volta às páginas do jornal, dessa vez em versos sob o mesmo título do artigo de alguns dias atrás, “A prostituição”. Também não vinha assinada, mas trazia a informação de que teria sido escrita em Campo Grande Realengo, em 10 de setembro de 1861. A idéia expressa na poesia era bastante semelhante à apresentada no artigo. Ambos os autores utilizavam o avesso do modelo senão para reforçarem o próprio modelo de inocência e candura femininas, conforme é possível verificar logo no início dela:

\author{
Mulher!.... do Creador obra querida, \\ Formosa como sol, na terra um anjo, \\ Cheia de pejo, de candura e graças \\ Mandada pelo céu, como a esperança, \\ Doce remédio aos males desse mundo, \\ Formada p'ra viver com pranto, e rizos, \\ Rizos do coração, e prantos d'alma!.... \\ Mulher!..... o que fizeste?..... Negra sombra \\ Aos olhos da razão, da naturesa, \\ Tuas graças do céo, por que escurece? \\ Que fizeste, ó mulher?... que às mãos de neve, \\ Aonde a compaixão, e a caridade \\ Contra os males da terra o céo puzera, \\ Hoje, ou são frias como as mãos da morte, \\ Ou são abrazadas como o inferno, \\ Que escalda o coração, que punge n'alma?... \\ [...] \\ (Jornal O Noticiador de Minas, edição 39, 21/11/1868).
}

Como tentamos demonstrar, os homens que contribuíram no Noticiador de Minas entre o final dos anos de 1868 até o final de 1872 pareciam ter em mente um modelo bem determinado ao falarem das mulheres, seja através dos gêneros narrativos, seja através dos poéticos. Para justificarem suas posições em relação ao alto lugar ocupado pela mulher no período - ideal de bondade e beleza , compartilhadas com muitos clérigos católicos que estão feminizando o catolicismo brasileiro naquele período, buscaram tanto argumentos "históricos", contrastando sua época a anteriores, consideradas mais bárbaras, quanto argumentos "antropológicos", ao diferenciarem a condição da mulher no Ocidente com as das mulheres asiáticas e africanas, ainda em estado lastimável de sujeição, segundo eles. 
Seja elogiando a candura e a caridade das mulheres diretamente, seja indiretamente, através da condenação de seu avesso, da prostituta, o que esses homens parecem ter tentado fazer, na verdade, foi resistir às pressões de mulheres - e homens mais liberais - para que fosse flexibilizada a hegemonia masculina no domínio dos poderes de decisão no mundo do trabalho e da política - o domínio delas no lar já estava de bom tamanho segundo eles, e não retirava a delicadeza, como supunham que seria se as damas entrassem nas disputas dos agressivos meios comerciais e da vida pública. A idealização parece ter sido também uma tentativa de desviarem da vista de seus leitores as novas mulheres que a modernidade possibilitava surgir.

Não deixa de ser revelador o fato de que concomitante à idealização do feminino, os colaboradores do Noticiador de Minas também parecem ter tentado outra maneira bem menos cortês de se livrarem do incômodo que aparentavam sentir em relação às mulheres: a utilização da ironia contra elas. Isso pode ser observado em muitos artigos. Por questões de limite de espaço trazemos aqui um caso ilustrativo. O artigo a "Curiosidade", edição 421 (21/03/1872), que diz com sarcasmo que as mulheres seriam movidas por esse sentimento:

\footnotetext{
Ouçamos Mme. Pussieux:

$<<$ A curiosidade tem perdido mais moças do que a inclinação. $>>$

Faço logo no princípio uma citação, por que sou doudo pelas citações... de mulheres; e depois para mostrar aos leitores a exactidão de um pensamento tão a propósito.

O que quer dizer curiosidade?

Entre os homens é uma palavra quase ininteligível.

Tem apenas applicação.

De bom grado a apagaríamos do diccionário, se não fosse a atenção que devemos a ellas.

Por que nenhuma palavra exprime tão admiravelmente este desmedido afan de inquerir, observar, tactear, averiguar e saber que tanto caracterisa o bello sexo.

As causas mais triviaes, singelas e correntes são objecto de sua curiosidade.

(Jornal O Noticiador de Minas, edição 421, 21/03/1872).
}

Após dar muitos exemplos em que a curiosidade põe a perder as mulheres, o autor anônimo conclui sua narrativa em tom de gracejo: 
Nos meus momentos de máo humor escrevi invectivas contra a mulher. E sei de boa fonte que as moças teram as minhas humildes producções fulminado com os raios de sua ira o meu nome obscuro.

Dirão os senhores sem dúvida, se as atacas nos teus escriptos com ou sem razão, o que as obriga a lê-los?

- Ora, o que as obriga a ler, a curiosidade.

(Jornal O Noticiador de Minas, edição 421, 21/03/1872).

Essas ridicularizações do feminino podem ser lidas como o sintoma de um mal-estar social de seu gênero, de uma percepção angustiante do questionamento de seu status superior até então inviolado. Se vangloriavam dessa forma para afastar um sentimento de ameaça que um "outro" representava:

O riso que zomba dos outros é, em geral, incenso que a pessoa queima no altar que construiu para si própria, um altar que se sabe ser vacilante. "Há um sintoma de fraqueza no riso", escreveu Baudelaire, um desesperado esperar contra toda a esperança.

(GAY, 1995 [1988], p.371-372).

No próprio artigo que vínhamos citando sobre a curiosidade feminina, o humor sarcástico andou bem próximo da agressão declarada, quando por exemplo o narrador torna explícito seu rancor em relação às mulheres retomando o Gênesis:

Por curiosidade perdeu a nossa mãi Eva toda a espécie humana, donde se deprehende que terrível cousa é a curiosidade.

Sem ella viviriamos ainda no estado primitivo de Innocencia, em que viveram nossos primeiros pais.

Habitaríamos um paraizo cheio de encantos.

Não verteríamos o suor de nosso rosto para ganhar o pão.... e o vinho.

Affagariamos a juba do leão.

Brincaríamos com o tigre.

E cobrir-nos-hiamos com a folha de figueira.

Em uma palavra, viviriamos felizes, sem pezares nem desgostos, e quem sabe, talvez sem inglezes.

Mas a maldita curiosidade estragou o nosso brilhante futuro.

Ao vir ao mundo a curiosidade encarnou-se na mulher.

(Jornal O Noticiador de Minas, edição 421, 21/03/1872).

Esse uso justamente da linguagem para ironizar as mulheres não deixa também de ser revelador da relação que ela tem com o falo, ou se preferirem, com o poder no período. A fala ainda era um símbolo do poder masculino. Ora, as mulheres não lutaram por outra coisa durante o século XIX senão exatamente por 
terem a sua fala reconhecida, legitimada, no espaço público. E nessa altura - início da década de setenta do XIX - já estavam bastante avançadas em suas conquistas. Lembremo-nos do periódico fundado e dirigido pela professora Francisca Senhorinha da Mota Diniz intitulado O Sexo Feminino em 1874, Campanha - MG (FARIA FILHO et al, 2005); ou do progressivo número de mulheres que ingressavam nas escolas de primeiras letras na província mineira (GOUVÊA, 2004 b); e ainda da crescente entrada das mulheres na profissão do magistério (FARIA FILHO et al, 2005).

\section{Considerações finais}

Como vimos, portanto, no que tange às questões de gênero, o que fica mais evidente nas páginas do Noticiador de Minas, principal periódico ouro-pretano remanescente do período, não é a reivindicação feminina, as perspectivas de mudanças inauguradas naquele século e que estavam sendo postas em prática em outros países no mesmo período. Pelo contrário, o que a escrita masculina do jornal nos revela é que os seus colaboradores estavam bastante armados contra essas possíveis mudanças. Pelo menos é isso que parece revelar a agressiva e ressentida ironia em relação às mulheres, também presente em suas páginas.

A reiterada idealização da beleza e da bondade femininas, e sua associação à reclusão do lar, também parecia estar relacionada à ansiedade dos homens que escreviam para aquele jornal em relação à possibilidade de as mulheres ocuparem legitimamente o espaço público. Conforme tentamos demonstrar, uma determinada leitura das referências cristãs foi feita nessa empresa masculina. Uma seleção das múltiplas possibilidades de leitura do texto bíblico parece ter sido operada com finalidades bastante específicas por um agrupamento social delimitado - um grupo de sujeitos masculinos - e em um contexto histórico determinado - período em que as reivindicações femininas se acirram no Brasil e no mundo. 
Voltar a esses antigos jornais, olhar o século XIX a partir do XXI, pode nos ajudar a ponderar sobre as mudanças e permanências nas relações de gênero no Brasil, bem como das mobilizações que são feitas do texto bíblico atualmente. Novas masculinidades e feminilidades se tornaram possíveis ao longo do século XX. Novas leituras da tradição cristã também foram empreendidas. Não podemos, entretanto, deixar de reconhecer, com pesar, que alguns resquícios do universo limitado das representações de feminino e de cristianismo veiculado no jornal oitocentista analisado pode ainda facilmente ser identificado em alguns nichos culturais em nosso Brasil dos anos dois mil. Reinventemos, pois, nossa tradição afim de que representações mais complexas de feminino se espraiem em nosso cotidiano e enriqueça a qualidade de nossa experiência humana. Novas leituras dos textos bíblicos podem ser fundamentais para esse empreendimento de mudanças culturais.

\section{REFERÊNCIAS}

ASSIS, Raquel Martins. Psicologia, Educação e Reforma dos costumes: lições da Selecta Catholica (1846-1847). 2004. 283f. Tese (Doutorado em Educação - Psicologia da Educação), Faculdade de Educação, Universidade Federal de Minas Gerais. Belo Horizonte, 2004.

DUARTE, Nestor. A ordem privada e a organização política nacional. $2^{\mathrm{a}}$ ed. São Paulo: Companhia Editora Nacional, 1966 [1939].

FARIA FILHO, Luciano Mendes de et al. A história da feminização do magistério no Brasil: balanço e perspectivas de pesquisa. In: PEIXOTO, A. M. C.; PASSOS, M. (Org.). A escola e seus atores - educação e profissão docente. Belo Horizonte: Autêntica, 2005. p.53-89.

GAY, Peter. A experiência burguesa da Rainha Vitória a Freud: a educação dos sentidos. São Paulo: Companhia das Letras, 1988 [1984].

GAY, Peter. A experiência burguesa da Rainha Vitória a Freud: o cultivo do ódio. São Paulo: Companhia das Letras, 1995 [1988].

GOUVÊA, Maria Cristina Soares. Meninas na sala de aula: dilemas da escolarização feminina no século XIX. In: FARIA FILHO, Luciano Mendes de (Org.). A infância e sua educação - materiais, práticas e representações (Portugal e Brasil). Belo Horizonte: Autêntica, 2004. p. 189-212. 
LIMA, Raquel; TEIXEIRA, Igor. Ser mãe: o amor materno no discurso católico do século XIX. Horizonte, Belo Horizonte, v. 6, n. 12, p. 113-126, junho de 2008.

MUZART, Zahidé Lupinacci. Uma espiada na imprensa das mulheres no século XIX. Revista Estudos Feministas, Florianópolis, v. 11, n.1, p. 225-233, jan./jun. 2003.

NOTICIADOR DE MINAS. “Jornais Mineiros”. Disponível em: <http://www.siaapm.cultura.mg.gov.br/> . Da edição $n^{\circ} 01$ (19/08/1868) até a última edição, $n^{\circ} 531$ (25/01/1873). Acesso em: 21 de fev. 2014.

PERROT, Michelle (Org.). História da Vida Privada, 4: Da Revolução Francesa à Primeira Guerra. São Paulo: Cia das Letras, 2009 [1987].

ROSADO NUNES, Maria José F. Le 19ème siècle: un tournant dans l'Eglise catholique et dans la vie des femmes au Brésil. Social Compass, Bélgica, v. 4, n. 43, p. 503-513, 1996.

SCOTT, Joan W. Gender and the politics of history. New York: Columbia University Press, 1999.

SIAAPM. Sistema Integrado de Acesso do APM. Disponível em:

<http://www.siaapm.cultura.mg.gov.br>. Acesso em: 21 de fev. de 2014.

ZICA, Matheus da Cruz. Diversificação dos modos de ser masculino e estatização da violência masculina na escrita literária e jornalística de Bernardo

Guimarães (1869-1872). 2011. Tese (Doutorado) - Universidade Federal de Minas Gerais - UFMG, Belo Horizonte. 